\title{
Gastropods from the Norian (Late Triassic) Nayband Formation near Natanz (Iran)
}

\author{
AlEXANDER NÜtZEL, BABAK AGHABABALOU \& BABA SENOWBARI-DARYAN
}

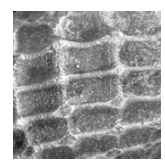

A collection of marine gastropods from the Late Triassic (Norian) Nayband Formation of Iran near Isfahan consists of 207 specimens representing 9 species ( 3 species are new). Rarefaction analyses and diversity indices indicate that the diversity of the studied fauna is much lower than that from the vicinity of Ali Abad (Tabas region) and somewhat less diverse than that of Dizlu (Isfahan region). All known gastropod faunas from the Nayband Formation are dominated by more or less high-spired caenogastropods. However, species composition and rank abundance of the most common taxa differ strongly in all three gastropod collections. The new species are Acilia? basistriata, Teutonica? natanzensis and Protorcula iranica. The present gastropod fauna is dominated by the caenogastropods Coelostylina conica, Protorcula iranica and Teutonica? natanzensis. Key words: Gastropoda, Nayband Formation, Iran, Triassic, taxonomy, diversity.

Nützel, A., Aghababalou, B. \& Senowbari-Daryan, B. 2012. Gastropods from the Norian (Late Triassic) Nayband Formation near Natanz (Iran). Bulletin of Geosciences 87(1), 53-65 (6 figures, 2 tables). Czech Geological Survey, Prague. ISSN 1214-1119. Manuscript received October 7, 2011; accepted in revised form November 10, 2011; published online November 25, 2011; issued February 29, 2012.

\begin{abstract}
Alexander Nützel, Bayerische Staatssammlung für Paläontologie und Geologie, Ludwig-Maximilians-University Munich, Department für Geo- und Umweltwissenschaften, Sektion für Paläontologie, Geobiocenter LMU, Richard Wagner Str. 10, 80333 München, Germany; a.nuetzel@Irz.uni-muenchen.de • Babak Aghababalou, Department of Sciences, Izeh Branch, Islamic Azad University, Izeh, Khuzestan, Iran; babakbabalou@gmail.com・Baba Senowbari-Daryan, GeoZentrum Nordbayern, Lehrstuhl für Paläontologie, Universität Erlangen-Nürnberg, Loewenichstraße 28, 91054 Erlangen, Germany; baba.senowbari-daryan@gzn.uni-erlangen.de
\end{abstract}

The Late Triassic (Norian/Rhaetian) Nayband Formation is highly fossiliferous and yielded an abundant marine invertebrate fauna (for a review Fürsich et al. 2005). Gastropods of the Nayband Formation were studied by Douglas (1929), Fallahi et al. (1983), Nützel \& Senowbari-Daryan (1999) and Nützel et al. (2003, 2010). About 40 gastropod species were reported from the Nayband Formation, most of them from the Tabas/Nayband area (Douglas 1929, Nützel \& Senowbari-Daryan 1999). Gastropods from the Isfahan area were reported by Fallahi et al. (1983) and Nützel et al. (2003, 2010). Here, a new collection of gastropods is reported from the Nayband Formation in the vicinity of Natanz. This fauna differs considerably in composition and rank abundance from other gastropod collections reported so far from the Nayband Formation. Relatively few fossil collections from the Nayband Formation have been reported, although it has a vast outcrop area (Fig. 1). This is the first report from the Natanz area. The collection comprises 207 gastropod specimens (exclusive of 2 undetermined specimens), some of them were accumulated in shell beds (Fig. 2A, B). They represent 9 species. In addition, a few bivalves are present in this collection (Palaeocardita cf. iranica var. multiradiata Hautmann, 2001; Fig. 2B, D).

\section{Geological setting}

The geological setting and location was described in detail by Hautmann et al. (2011) who discussed the bivalve Trigonucula (Gonionucula) aciloides; direct quote from Hautmann et al. (2011): "The material studied was collected from the Late Triassic Nayband Formation in central Iran, north of the city of Isphahan. The fossil locality is located at the western slope of the Kuh-e Panjar mountain in the Karkas Range, $90 \mathrm{~km}$ north of Isphahan and $30 \mathrm{~km}$ south of Natanz, at N $33^{\circ} 16^{\prime} 08.6^{\prime \prime}$, E $51^{\circ} 50^{\prime} 28.5^{\prime \prime}$ (Fig. 1). In this area, the thickness of the Nayband Formation varies between, $720 \mathrm{~m}$ (Fallahi 1980, Fallahi et al. 1983) and, $1400 \mathrm{~m}$ (Zahedi 1973, Seyed-Emami 2003) and is thus distinctly thinner than at the type locality in eastcentral Iran, where a maximum thickness of nearly $3 \mathrm{~km}$ is reached (Kluyver et al. 1983, Hautmann 2001, Fürsich et al. 2005). A major sedimentary hiatus between the Nayband Formation and the underlying Espahk Member of the Shotori Formation, as observed in east-central Iran, has not been confirmed in the area north of Isphahan (Seyed-Emami 2003). A local subdivision of the Nayband Formation in this area was proposed by Zahedi (1973), 


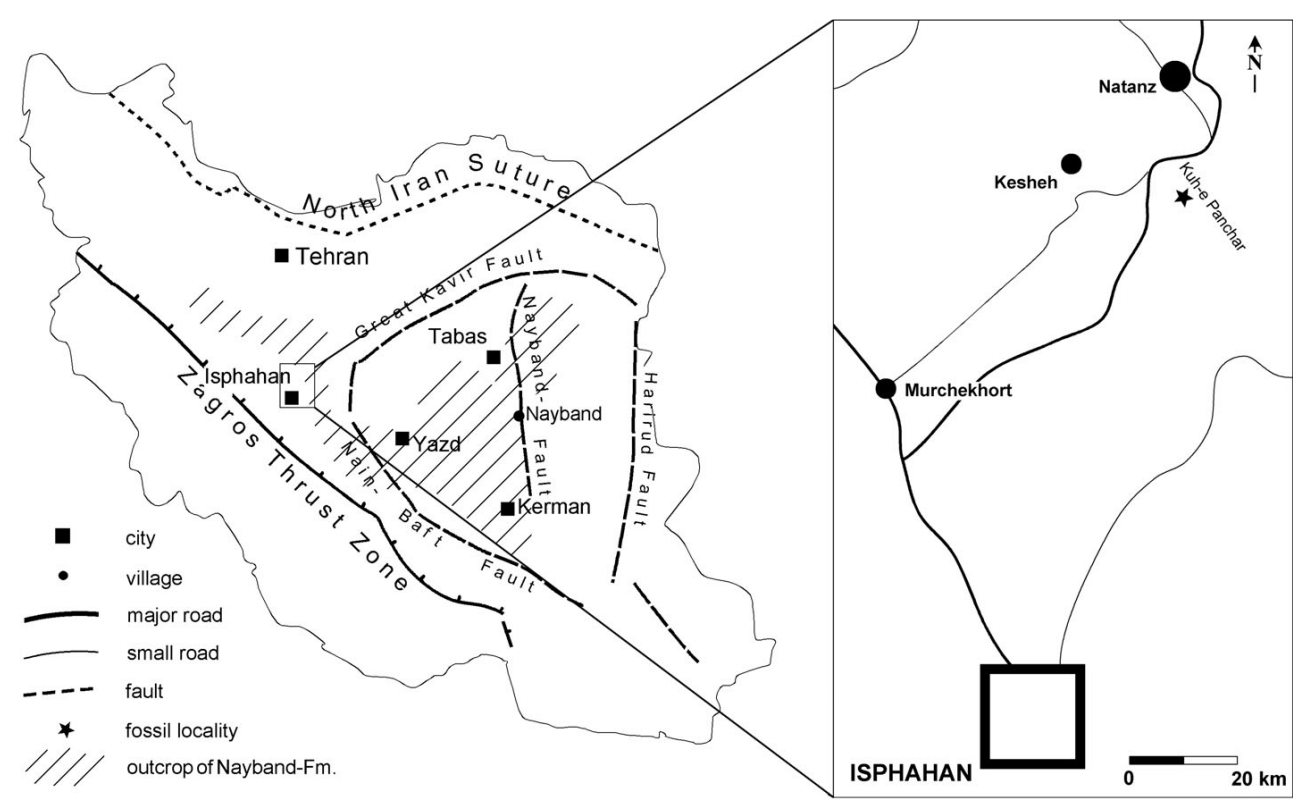

Figure 1. Locality map from Hautmann et al. (2011) used with permission from the $\mathrm{Pa}$ leontological Society (Journal of Paleontology).

who distinguished four informal members. The basal 'Serie de transition' (up to $70 \mathrm{~m}$ ) shows a lithological transition from limestone-dolomite alternations to shales and limestones containing Indopecten and Distichites. The following 'Schiste et calcaire de Parsefid' (up to $340 \mathrm{~m}$ ) is an alternation of dark shales and sandy shales with few intercalations of limestones and marly limestones containing bivalves and ammonoids. It is this interval where our material comes from. The overlaying 'Schiste et grès de Venher' (up to $510 \mathrm{~m}$ ) is comprised of dark shales and greyish sandstones devoid of fossils, followed by the 'Schiste et calcaires de Niazmargh' (up to $500 \mathrm{~m}$ ), which consists of greyish shales with limestone and sandstone intercalations and contains corals, bivalves, including the late Norian Monotis salinaria Schlotheim, and the conspicuous spherical, colonial hydrozoan Heterastridium. At the fossil locality, an approximately $60 \mathrm{~m}$ thick part of the 'Schiste et calcaire de Parsefid' is exposed, which consists of sandstones and marls with two intercalated units of marly limestones approximately $40 \mathrm{~m}$ apart. The lower of these marly limestone units contains the ammonoid species Distichites tozeri SeyedEmami, Arcestes sp., and Pinacoceras imperator Mojsisovics, indicating a late Middle Norian age (Alaunian 3). The upper limestone unit is rich in bivalves, including the taxon described in this study. Given the comparatively high sedimentation rates of the Nayband Formation, as indicated by the high thickness of sediments deposited in the late Middle Norian to Rhaetian time interval, the material examined here is assumed to be Alaunian 3 in age as well."

Preservation. - The gastropod shells were replaced by a blackish calcite. Protoconchs and apertures are not preserved; however, details of the teleoconch ornamentations are commonly well-preserved. Most of material is present as isolated specimens. In addition, two small fragments of thin shells beds contain abundant gastropods and bivalves indicating taphonomic concentration processes (Fig. 2A, B).

Repository. - The studied material is housed in the Bayerische Staatssammlung für Paläontologie und Geologie (Bavarian State Collection for Palaeontology and Geology), Richard Wagner Str. 10, 80333 München, Germany under the numbers BSPG 2011 XXXIV 1-30.

\section{Systematic paleontology}

Class Gastropoda Cuvier, 1795

Superorder Vetigastropoda Salvini-Plawen, 1980

Family ?Turbinidae Rafinesque, 1815

?Turbinidae gen. and sp. indet.

Figure 3A

Material. - One specimen, BSPG 2011 XXXIV 8.

Description. - Shell turbiniform; teleoconch fragment of about three whorls, $10.5 \mathrm{~mm}$ high (apex missing), $11.5 \mathrm{~mm}$ wide; whorls convex, without visible ornament; sutures incised; base flatly convex, joining whorl face at rounded edge.

Remarks. - The present specimen represents a distinct species in this collection. However, its preservation is so poor that any identification and assignment is impossible. The specimen resembles the vetigastropod genus Striatoconulus Gründel, 2000 but lacks any preserved spiral ornament. 
Subclass Caenogastropoda Cox, 1960

Family Prostyliferidae Bandel, 1992

\section{Genus Acilia Koken, 1896}

Type species. - Acilia aequalis Koken, 1896, Late Triassic, N Alps, Austria.

\section{Acilia? basistriata sp. nov.}

Figure 3B

Holotype. - The only specimen, BSPG 2011 XXXIV 5.

Etymology. - Latin for spiral ribs present on the base of this shell.

Stratum typicum. - Late Triassic Nayband Formation, Alaun 3, late Middle Norian, Nayband Formation.

Locus typicus. $-90 \mathrm{~km}$ north of Isfahan and $30 \mathrm{~km}$ south of Natanz, GPS: N $33^{\circ} 16^{\prime} 08.6^{\prime \prime}$, E 51 50’ 28.5".

Diagnosis. - Conical to turbiniform shell; whorls convex; whorl face smooth; sutures deeply incised; base distinctly convex, evenly rounded when joining whorl face; base covered with five very strong spiral ribs and weaker spiral ribs between main spirals; aperture oblique oval.

Description. - Shell conical turbiniform; teleoconch fragment of about 3.5 whorls, $14.2 \mathrm{~mm}$ high (apex missing), $11 \mathrm{~mm}$ wide; whorls distinctly convex; whorl face smooth; sutures deeply incised; base distinctly convex, evenly rounded when joining whorl face; base covered with five very strong spiral ribs and weaker spiral ribs between main spirals; base seemingly minutely phaneromphalous or having a pseudo-umbilicus; aperture oblique oval, higher than wide.

Remarks. - Acilia? basistriata sp. nov. is a very characteristic species especially because of the very strong spiral ribs on the base which are not present in other Acilia species. The generic assignment is tentative until more complete specimens become available. The combination of conical smooth spire whorls with a base with very strong spiral ribs is to our knowledge unique in for Triassic gastropods and thus, the present species may represent a new genus.

Family Coelostylinidae Cossmann, 1909

\section{Genus Coelostylina Kittl, 1894}

Type species. - Melania conica Münster, 1841, Carnian, Cassian Formation, Alps.

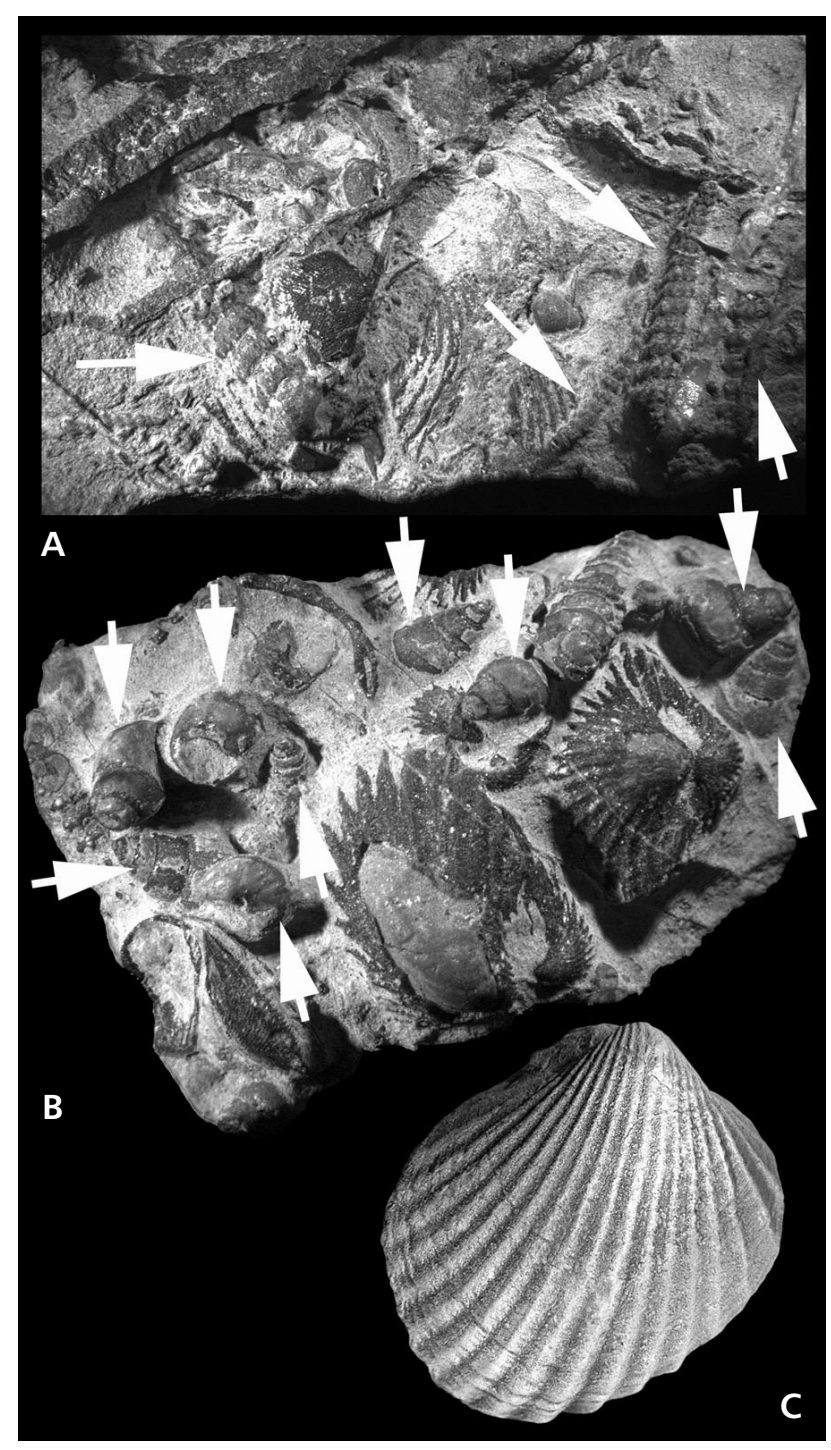

Figure 2. A - slab with several specimens of Teutonica? natanzensis sp. nov., paratypes, arrows, BSPG 2011 XXXIV 23, width $4 \mathrm{~cm}$. $\bullet$ B - slab with several specimens of Coelostylina conica (Münster, 1841) (arrows), BSPG 2011 XXXIV 22; width $26 \mathrm{~mm}$. C - Palaeocardita cf. iranica var. multiradiata Hautmann, 2001, BSPG 2011 XXXIV 1, length $15.5 \mathrm{~mm}$.

\section{Coelostylina conica (Münster, 1841)}

Figures 2B, 3C-E

*1841 Melania conica n. sp. - Münster, p. 94, pl. 9, fig. 21.

1894 Coelostylina conica. - Kittl, p. 181, pl. 5, fig. 1-7.

?1929 Coelostylina sp. - Douglas, p. 640.

1992 Coelostylina conica. - Bandel, p. 55, pl. 6, fig. 6, pl. 7, figs 1, 2, 5, 6 .

1999 Coelostylina conica. - Nützel \& Senowbari-Daryan, p. 120 , pl. 5 , fig. 12 , pl. 8 , figs 6,7 .

For further synonymy see Kittl (1894), the Fossilium Catalogus (Diener 1926, Kutassy 1940) and Bandel (1992). 
Material. - 113 specimens: three illustrated ones (BSPG 2011 XXXIV 2-4), 72 specimens (BSPG 2011 XXXIV 24), at least 25 specimens on limestone slab (Fig. 2B, BSPG 2011 XXXIV 22), at least 13 specimens on limestone slab (Fig. 2A, BSPG 2011 XXXIV 23).

Description. - Shell conical, moderately high-spired; specimen illustrated in Fig. 3E comprises about 6 whorls, is $7 \mathrm{~mm}$ high and $4 \mathrm{~mm}$ wide; whorls moderately convex with narrow rounded subsutural shoulder; sutures distinctly impressed; base rounded convex, minutely phaneromphalous; shell smooth, growth-lines not visible; aperture oval.

Remarks. - The present specimens are very similar to C. conica from the Cassian Formation as figured by Kittl (1894) and Bandel (1992). A direct comparison with Münster's (1841) type specimen from the Cassian Formation (BSPG AS VII 504) provided no differences except that the present material is distinctly smaller. Therefore, we assign the present material to $C$. conica though Münster's (1841) type material is much older (Early Carnian). Coelostylina conica was also reported from the Nayband Formation at Ali Abad (Howz-e Khan Member) by Nützel \& Senowbari-Daryan (1999). Douglas (1929) and Nützel et al. (2010) mentioned poorly preserved specimens of Coelostylina from the Isfahan area.

\section{? Family Zygopleuridae Wenz, 1938}

\section{Genus Katosira Koken, 1892 (in Wöhrmann \& Koken)}

Type species. - Katosira fragilis Koken, 1892 (in Wöhrmann \& Koken), Carnian, Alps.

Remarks. - Previously, the Jurassic K. periniana was erroneously considered to be type species of Katosira (Cossmann 1909; Wenz 1938). Katosira was introduced two times as a new genus (Koken in Wöhrmann \& Koken, 1892, p. 205; Koken 1892, p. 31). Koken in Wöhrmann \& Koken (1892) did not mention Katosira periniana and included only Katosira? abbreviata Koken, 1892 and K. fragilis Koken, 1892. If this publication has priority, Katosira fragilis would be the type species because Katosira? abbreviata was assigned to Katosira only tentatively. However, in the other publication Koken (1892) included Katosira periniana and K. fragilis in Katosira. Subsequently, Cossmann (1908) designated $K$. periniana as type species which was accepted by Wenz (1938). According to Knight et al. (1960) and Szabó (2008), the Upper Triassic K. fragilis is type species which seems to be correct. Koken in Wöhrmann
\& Koken (1892) was published in the April-June issue (probably April) while Koken (1892) was published in the second of two volumes so probably post-June 1892.

\section{Katosira? lateplicata (Klipstein, 1843)}

Figure 3G

1843 Cerithium lateplicatum n. sp. - Klipstein, p. 182, pl. 11, fig. 35.

?1894 Katosira (?) lateplicata. - Kittl, p. 164, pl. 4, figs 27, 28.

?1978 Katosira seelandica.-Zardini, p. 44, pl. 28, figs 7, 8.

?1978 Katosira lateplicata. - Zardini, p. 44, pl. 28, fig. 9.

non 1995 Camponaxis (?) lateplicata (Klipstein, 1843). - Bandel, p. 27, pl. 13, fig. 9, pl. 14, figs 1-5.

Material. - Two specimens, BSPG 2011 XXXIV 14, 25.

Description. - Shell high-spired, fusiform; teleoconch fragment comprises 4-5 whorls, $25 \mathrm{~mm}$ high, $12.5 \mathrm{~mm}$ wide; teleoconch whorls distinctly convex with rounded angulation at middle of spire whorls; whorls ornamented with strong axial ribs numbering 8-9 per whorl; axial ribs round, broad, forming axially elongated nodes at periphery; axial ribs weak near adapical suture; whorls ornamented with numerous (up to 20) fine spiral ribs; thinner and thicker spiral ribs alternate with each other; spiral ribs may be stronger when crossing axial ribs, but not nodular.

Remarks. - This characteristic shell closely resembles Katosira? lateplicata (Klipstein, 1843) as illustrated by Klipstein (1843, pl. 11, fig. 35) from the Carnian Cassian Formation (South Tyrol, N Italy). However, Klipstein's (1843) specimen has more axial ribs per whorl. The specimens illustrated as $K$.? lateplicata by Laube (1868) and Kittl (1894) are more slender than Klipstein's typethey are probably not conspecific. The specimens from the Cassian Formation illustrated as $K$. seelandica Kittl, 1894 by Zardini (1978, pl. 28, figs 7, 8) closely resemble our Iranian specimens. The Cassian specimen figured by Zardini (1978, pl. 28, fig. 9) as K. lateplicata has lower and evenly convex whorls and more ribs per whorls than the present specimens. Katosira seelandica Kittl, 1894 from the Cassian Formation is similar but has stouter whorls and the periphery is not as angular and lacks elongated axial nodes. Bandel (1995) designated K. lateplicata as type species of the mathildoid Camponaxis Bandel, 1995. However, the material illustrated by Bandel (1995) is very slender and small; therefore it may prove that the type species of Camponaxis was misidentified. 


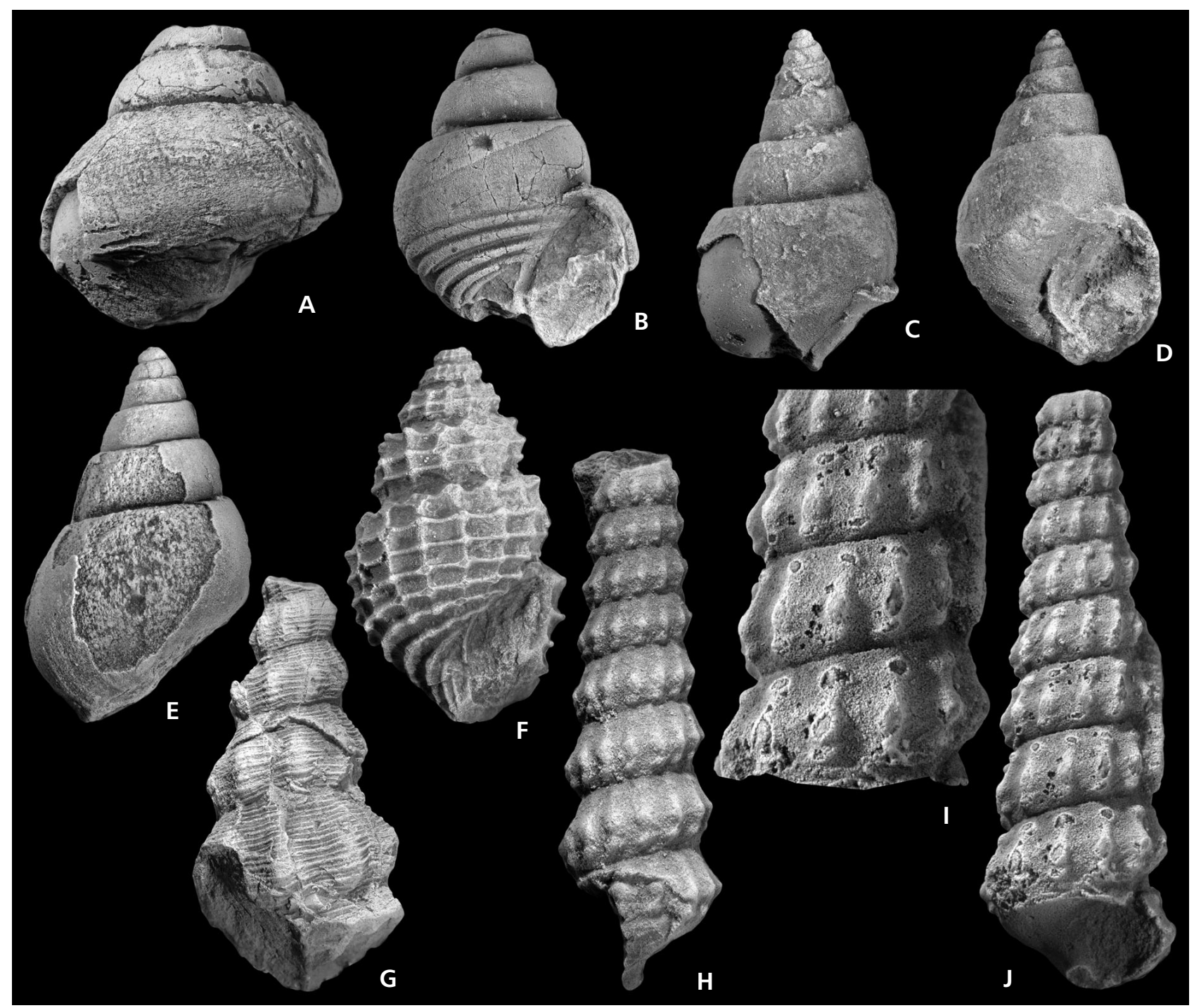

Figure 3. A - turbinid indet., BSPG 2011 XXXIV 8, height $10.4 \mathrm{~mm}$. B - Acilia? basistriata sp. nov., holotype, BSPG 2011 XXXIV 5, height $14.2 \mathrm{~mm}$ • C C-E - Coelostylina conica (Münster, 1841). C - BSPG 2011 XXXIV 2, height $3.8 \mathrm{~mm}$; D - BSPG 2011 XXXIV 3, height $3.3 \mathrm{~mm}$; E - BSPG 2011 XXXIV 4, height $7.0 \mathrm{~mm}$. - F - Rhynchocerithium douglasi Nützel \& Senowbari-Daryan, 1999, BSPG 2011 XXXIV 6, height 8.5 mm. - G - Katosira? lateplicata (Klipstein, 1843), BSPG 2011 XXXIV 14, height $25 \mathrm{~mm} \cdot \bullet \mathrm{H}-\mathrm{J}$ - Teutonica? natanzensis sp. nov. H - holotype, BSPG 2011 XXXIV 17, height $8.5 \mathrm{~mm}$. I, J - paratype, BSPG 2011 XXXIV 28. I - detail of teleoconch, height $4 \mathrm{~mm}$; J - height $10 \mathrm{~mm}$.

Family Procerithiidae Cossmann, 1906

\section{Genus Rhynchocerithium Cossmann, 1906}

Type species. - Cerithium fusiforme Hébert \& Eudes-Deslongchamps, 1860, Callovian, France.

\section{Rhynchocerithium douglasi Nützel \&}

Senowbari-Daryan, 1999

Figure 3F

1929 Scalaria aff. elegans (Münster). - Douglas, p. 639, pl. 44 , fig. 6 .
*1999 Rhynchocerithium douglasi $\mathrm{n}$. sp. - Nützel \& Senowbari-Daryan, p. 108, pl. 3, figs 11-13, pl. 4, fig. 1.

2003 Rhynchocerithium douglasi. - Nützel et al., p. 130, pl. 24, figs 12-14.

Material. - One specimen, BSPG 2011 XXXIV 6.

Description. - Shell fusiform; specimen with about six whorls, $8.5 \mathrm{~mm}$ high, $4.8 \mathrm{~mm}$ wide (apex missing); whorls convex with deep sutures and subsutural ramp; whorls ornamented with distinct narrow axial and spiral ribs; axial ribs straight, orthocline; intersections of spiral and axial ribs nodular to spine-like; axial ribs stronger toward adapical 
spiral rib so that nodules on adapical spiral are most prominent (often spine-like); 14-15 axial ribs per whorl; axial ribs end somewhat before adapical suture; spiral ribs nearly of equal strength; adapical spiral borders subsutural ramp; distance between adapical spiral rib and middle spiral rib somewhat wider than between middle and abapical spiral; another spiral rib partly exposed at abapical suture; base convex; transition whorl-face to base evenly rounded; six additional spiral ribs on base; axial ribs continue onto base but cease towards centre of base; growth-lines orthocline; aperture higher than wide, oval.

Remarks. - The present specimen from the Natanz area agrees well with the type material of Rhynchocerithium douglasi from the Nayband Formation at Ali Abad (Tabas area) as reported by Nützel \& Senowbari-Daryan (1999). At Ali Abad, it is one of the most common gastropod species. Nützel et al. (2003) showed that the specimen which was reported by Douglas (1929) as Scalaria aff. elegans (Münster, 1841) from the Nayband Formation near Isfahan represents $R$. douglasi. It is noteworthy, that this species was not present in the collection from the Nayband Formation near Dizlu studied by Nützel et al. (2010).

Family Polygyrinidae Bandel 1993

\section{Genus Teutonica Schröder 1991}

Type species. - Teutonica gramanni Schröder, 1991, Middle Jurassic, Germany, Poland.

Teutonica? natanzensis sp. nov. Figures 2A, 3H-J

\section{Holotype. - BSPG 2011 XXXIV 17.}

Paratypes. - 31 specimens: BSPG 2011 XXXIV 28 (illustrated), 15, 16, 29, 26 (19 specimens) and at least 8 additional specimens on limestone slab (Fig. 2A, BSPG 2011 XXXIV 23).

Etymology. - After the town of Natanz, Iran.

Stratum typicum. - Late Triassic Nayband Formation, Alaun 3, late Middle Norian, Nayband Formation.

Locus typicus. $-90 \mathrm{~km}$ north of Isfahan and $30 \mathrm{~km}$ south of Natanz, GPS: N $33^{\circ} 16^{\prime} 08.6^{\prime \prime}$, E 51 ${ }^{\circ} 50^{\prime} 28.5^{\prime \prime}$.

Diagnosis. - Small, high-spired, slender shell with numerous low whorls; whorls ornamented with axial ribs which form two spiral rows of axially elongated nodes; upper row of nodes stronger than lower one, situated at mid-whorl forming angular periphery of whorls; lower row of nodes weaker, situated between abapical suture and upper row of nodes; a third row of relatively weak nodes is present in subsutural position of mature whorls.

Description. - Shell high-spired, slender with numerous low whorls; holotype teleoconch fragment of 7 whorls, $8.5 \mathrm{~mm}$ high, $3 \mathrm{~mm}$ wide; largest specimen teleoconch fragment of 9 whorls, $10 \mathrm{~mm}$ high, $3 \mathrm{~mm}$ wide was probably originally as high as $12 \mathrm{~mm}$ (BSPG XXXIV 28, apex missing); teleoconch whorls distinctly convex with rounded angulation at mid-whorl or somewhat below; sutures distinct; whorls low, ornamented with 12-13 opisthocyrt to straight axial ribs per whorl which form two spiral rows of axially elongated nodes; upper row of nodes stronger than lower one: upper row situated at mid-whorl forming angular periphery of whorls; lower row of nodes weaker, situated between abapical suture and upper row of nodes; third subsutural row of nodes present on mature whorls; ribs weak near sutures; base flatly convex.

Remarks. - Teutonica? natanzensis is a characteristic species although protoconch and aperture are unknown. It probably represents a polygyrinid or cerithioid caenogastropod. However, a placement in Mathildoidea is also possible. Teutonica? natanzensis resembles the Jurassic type species of Teutonica in general shape and in having low, distinctly convex whorls. Teutonica has usually round, wide axial ribs instead of nodular rows. However, the Jurassic Teutonica gramanni nodosa Gründel, 1999 has a single row of strong axially elongated nodes and is rather close to Teutonica? natanzensis which has two to three rows of nodes.

Teutonica? natanzensis is also similar to the Jurassic polygyrinid genus Acanthostrophia Conti \& Fischer, 1984 (see Kaim \& Conti 2010). However, Acanthostrophia has nodes near the suture. It also resembles Cretaceous species of the genus Ageria Abbass, 1973, a putative ptenoglossan, but these species have stronger axial ribs and even the spiral ornament is stronger (Kaim et al. 2004, Tracey 2010). It also resembles the juvenile teleoconch morphology of Cretaceous species of the genus Metacerithium Cossmann, 1906 as reported by Kiel (2006) and Tracey (2010). However, mature teleoconch whorls have a dominant spiral ornament and a siphonal canal.

Teutonica? natanzensis also resembles the wide-spread and diverse Mesozoic genus Cryptaulax. Usually, Cryptaulax including $C$. inaequelineata (Nützel \& Senowbari-Daryan, 1999) from the Nayband Formation has distinct spiral ribs whereas the present species has only spirally arranged nodes which are connected only with very weak spiral ribs. Cryptaulax? hautmanni Nützel et al., 2010 from the Nayband Formation near Isfahan (location 
Dizlu) differs from T.? natanzensis in having a median nodular main spiral which angulates the whorls and in having a subsutural row of fine nodes which are more numerous than the nodes on the median spiral rib. Moreover, C.? hautmanni has only very weak axial ribs. Cryptaulax? convexa Nützel et al., 2003 differs from T.? natanzensis from the Nayband Formation near Isfahan in being much larger and in having three equally spaced rows of nodes on the axial ribs of the whorls.

Teutonica? natanzensis probably represents a new genus but its preservation is too poor to characterize this genus sufficiently. For a safe assignment, knowledge about the protoconch morphology is needed.

Family Protorculidae Bandel, 1991

\section{Genus Protorcula Kittl, 1894}

Type species. - Turritella subpunctata Münster, 1841, Late Triassic, Cassian Formation.

\section{Protorcula iranica sp. nov.} Figure 4A-M

Diagnosis. - High-spired medium-sized shell with straight flanks; whorl face variable from distinctly concave to straight or slightly convex; transition to base angular, formed by rounded edge which forms a bulge that is rarely somewhat nodular; basal edge directly at abapical suture or somewhat above forming suprasutural angulation; subsutural bulge distinct to almost absent; sutures distinct; whorls densely covered with fine spiral furrows of varying strength; early teleoconch whorls slightly convex with opisthocyrt axial ribs crossed by spiral threads.

Holotype. - BSPG 2011 XXXIV 9 (Fig. 4D, E).

Paratypes. - 53 specimens: 7 illustrated specimens, BSPG 2011 XXXIV 10, 11, 18, 20, 21, 30 and 47 additional specimens, BSPG 2011 XXXIV 27.

Etymology. - After Iran.

Stratum typicum. - Late Triassic Nayband Formation, Alaun 3, late Middle Norian, Nayband Formation.

Locus typicus. $-90 \mathrm{~km}$ north of Isfahan and $30 \mathrm{~km}$ south of

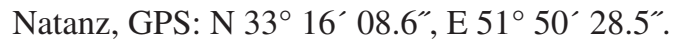

Description. - Shell high-spired conical with straight flanks; holotype (Fig. 4D, E) is a teleoconch fragment of about four whorls, $13 \mathrm{~mm}$ high, $6 \mathrm{~mm}$ wide; largest specimen (teleoconch fragment with missing apex and aper- ture) consists of six whorls, $51 \mathrm{~mm}$ high, $25 \mathrm{~mm}$ wide (reconstructed height at least $60 \mathrm{~mm}$ ); whorl sides variable from distinctly concave to straight or slightly convex; transition to base angular, formed by rounded edge which forms a bulge that is rarely somewhat nodular; basal edge directly at abapical suture or somewhat above forming suprasutural angulation; subsutural bulge distinct to almost absent; sutures distinct; whorls densely covered with fine spiral furrows of varying strength; early teleoconch whorls of paratype BSPG 2011 XXXIV 10 (Fig. 4K-M) with 15 slightly opisthocyrt axial ribs per whorl; these axial ribs crossed by about 8 spiral threads; these early whorls are slightly convex whereas later ones are straight to slightly concave; base flatly conical; aperture and protoconch unknown.

Remarks. - The present specimens assigned to Protorcula iranica sp. nov. show a considerable variability especially in the morphology of the abapical edge of the whorls which is sometimes elevated and sometimes bears weak nodules. Given the similarity in shape and the presence of spiral furrows, this is interpreted as intraspecific variability. Protorcula iranica sp. nov. resembles Protorcula cf. subpunctata (Münster, 1841) from the Nayband Formation (Bidestan and Howz-e Khan Members) of the Tabas area as illustrated by Nützel \& Senowbari-Daryan (1999, pl. 4, figs 9-11). However, these specimens have well developed subsutural nodes and are somewhat broader. Suprasutural nodes are also mostly absent in $P$. iranica while they are present in Protorcula species from the Carnian Cassian Formation (South Tyrol, N Italy) including P. subpunctata (e.g., Kittl 1894, Zardini 1978, Bandel 1991, Nützel 1998). Protorcula excavata (Laube, 1868) from the Cassian Formation also lacks nodes near the suture but is much smaller and has lower and more concave whorls. Protorcula iranica sp. nov. also resembles Anulifera binodosa (Fallahi et al. 1983) from the Nayband Formation and A. variabilis Zapfe, 1962 from the latest Triassic of the N Alps in shape and in having a fine spiral striation (see Nützel et al. 2010). However, Anulifera is characterized by one or two suprasutural rows of nodules and its whorls are not concave. The Late Triassic genus Chulitnacula Frýda \& Blodgett, 2001 is similar but has a pronounced row of nodules well above the abapical suture which angulates the whorl profile. Chulitnacula jenningsi (Douglas, 1929) from the Nayband Formation near Isfahan also shows this character and lacks any spiral striation (Nützel \& Senowbari-Daryan 1999, Nützel et al. 2003). Pseudokatosira? seminodosa (Nützel \& Senowbari-Daryan, 1999) from the Nayband Formation is another high-spired gastropod with a fine spiral ornament on the whorls. However, this species is characterized by large, axially elongated suprasutural nodes (Nützel et al. 2010).

The early teleoconch (not protoconch) with axial ribs crossed by spiral threads as present in one of the paratypes 
(Fig. 4M) is untypical for protorculids which have axially ribbed larval shells followed immediately by the typical protorculid teleoconch ornament (see Bandel 1991, Nützel 1998). Similar changes of teleoconch ornament have been reported from Triassic and Jurassic species assigned to the genus Anoptychia Koken, 1892 (Nützel 1998, Szabó 2008). However, at least the Triassic type species of this genus lacks any spiral ornament on the whorl face of the teleoconch. The high-spired and spirally striated Late Triassic gastropod genus Acrocosmia Koken, 1897 has an axially ribbed early teleoconch very similar to that shown here (Koken 1897, pl. 17, fig 4b). However, Acrocosmia has no concave whorls and no bulges at the sutures. Even the high spired caenogastropod genus Pseudokatosira Nützel \& Gründel, 2007 (Early Jurassic, Germany) with fine spiral teleoconch ornament has a similar early teleoconch ornament that changes subsequently during ontogeny. However, among other characters, Pseudokatosira differs from $P$. iranica in having axial ribs on the mature teleoconch.

As outlined by Nützel et al. (2010), it seems to be likely that the high-spired, commonly rather large Late Triassic caenogastropods with a fine spiral teleoconch striation and commonly rows of nodes near the sutures are closely related to each other: Protorcula, Anulifera, Chulitnacula and others. They form an important component of Late Triassic gastropod faunas.

Subclass Heterobranchia, 1837

Family Mathildidae Dall, 1889

\section{Genus Carinathilda Gründel, 1997}

Type species. - Carinathilda carinata Gründel, 1997; Middle Jurassic; NW Poland.

\section{Carinathilda? textilis (Nützel \& Senowbari-Daryan, 1999)}

Figure 5A, B

1999 Promathildia? textilis n. sp. - Nützel \& SenowbariDaryan 1999, p. 126, pl. 6, figs. 11, ?12.

Material - Two specimens, BSPG 2011 XXIV 13, 19.
Description. - Shell high-spired; illustrated specimen $21.5 \mathrm{~mm}$ high, $10 \mathrm{~mm}$ wide; whorl profile distinctly angulated at prominent keel below mid-whorl; whorls with reticulate ornament of fine spiral and axial threads; about 10 spiral threads on whorl-face; strong, keel-like spiral situated half way between main keel and abapical suture; remaining spiral threads nearly of equal strength, except the first to third adapical ones and the last abapical one which are a slightly more pronounced; numerous collabral, closely spaced, axial threads; axial threads oblique opisthocline between adapical suture and keel; axial threads straight and slightly opisthocline below keel.

Remarks. - The present specimens agree well with the holotype of Carinathilda? textilis from the Nayband Formation at Schurabi-Kusveh, Parvadeh, east-central Iran (?Bidestan Member). Promathilda sp. from the Carnian of Slovenia (Kaim et al. 2005) is similar but has fewer and coarser spiral ribs. Carinathilda? textilis resembles some of the Middle Jurassic mathildids that were figured by Gründel (1997). Species of the genera Carinathilda Gründel, 1997, Jurilda and Tricarilda Gründel, 1973 are similar in the teleoconch angulation and the reticulate ornament. Carinathilda has the same type of ornamentation as the present material; however, the base of Carinathilda is very convex and rounded which seems not to be the case in Carinathilda? textilis although the state of this character is not really clear due to preservation. A correct taxonomic placement is still not possible. An assignment to Promathildia as previously suggested by Nützel \& SenowbariDaryan (1999) seems to be unlikely because the type species of this genus differs considerably (Gründel \& Nützel, personal observation) though we still consider it to belong to Mathildoidea.

\section{Genus Teretrina Cossmann, 1912}

Type species. - Turritella bolina Münster, 1841, Carnian, Cassian Formation.

Remarks. - Turritella bolina, type species of Teretrina, lacks axial ribs and has strong spiral cords; this separates it from Mathilda and most other mathildoids.

Figure 4. Protorcula iranica sp. nov. - A, B - paratype with distinctly concave whorls, BSPG 2011 XXXIV 18. A - detail showing spiral striation, height $14 \mathrm{~mm}$; B - height $29 \mathrm{~mm}$. $・ \mathrm{C}$ - paratype with straight to slightly convex whorls, BSPG 2011 XXXIV 11. • D, E-holotype, BSPG 2011 XXXIV 9. D - height $13 \mathrm{~mm}$; E - detail with spiral striation, height $7 \mathrm{~mm}$. $\bullet \mathrm{F}, \mathrm{G}$ - paratype with elevated, protruding abapical edge that is slightly nodular, BSPG 2011 XXXIV 20. F - height 31 mm; G - detail showing spiral striation and nodular, elevated edge, height 13 mm. • H, I - paratype, BSPG 2011 XXXIV 21. H - detail apical whorls, height $28 \mathrm{~mm}$; I - height $40 \mathrm{~mm}$. $\bullet \mathrm{J}$ - paratype without visible spiral ornament and with oblique to parasigmoidal growth lines, BSPG 2011 XXXIV 30, 17 mm high. $\bullet$ K-M - paratype with preserved axially ribbed early teleoconch whorls, BSPG 2011 XXXIV 10. $\mathrm{K}$ - height $17 \mathrm{~mm}$; L - detail of mature teleoconch whorls with spiral striation, height $6 \mathrm{~mm}$; M - apical teleoconch whorls with axial ribs and spiral threads; width of first preserved whorl $1.2 \mathrm{~mm}$. 


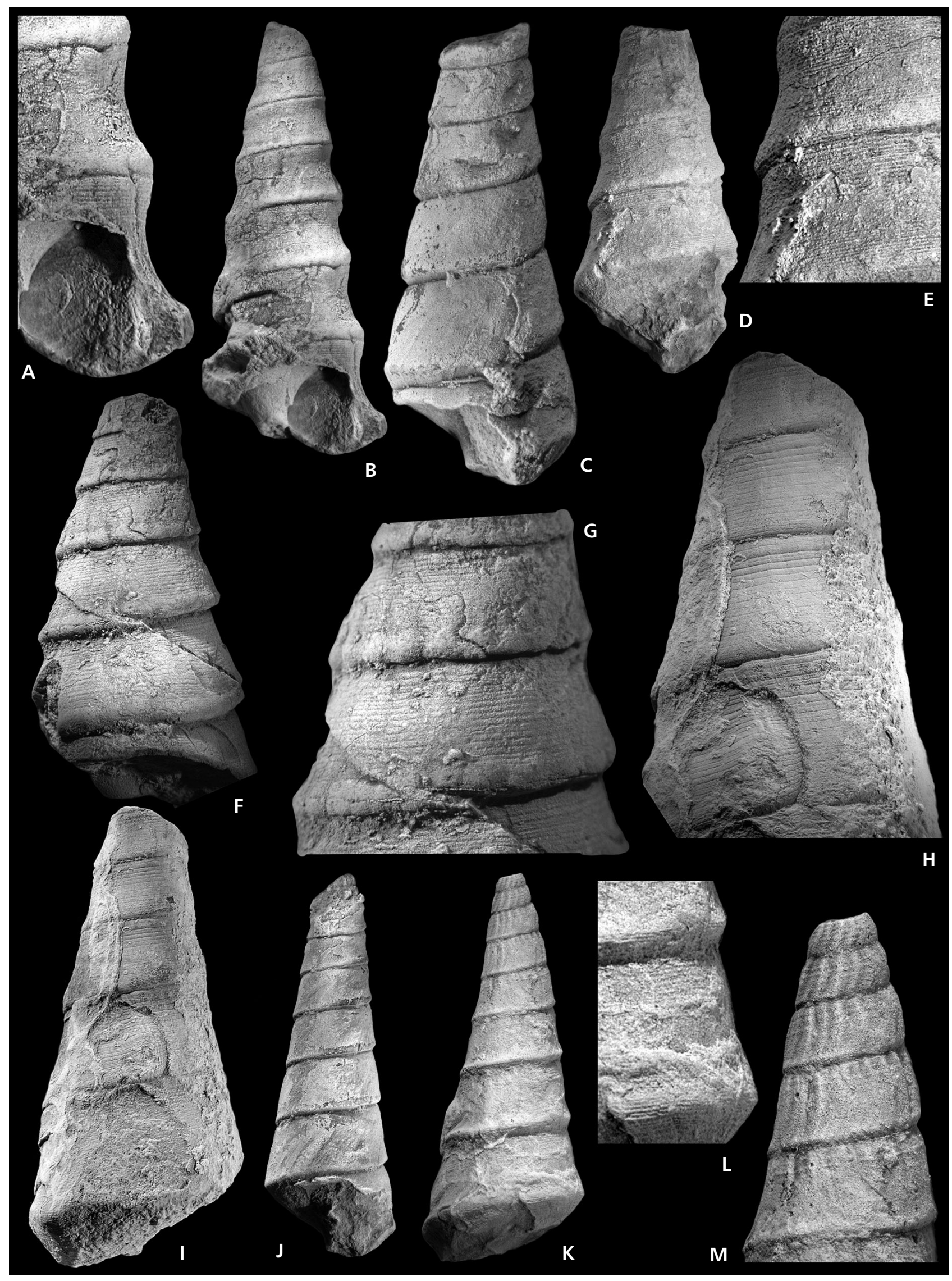




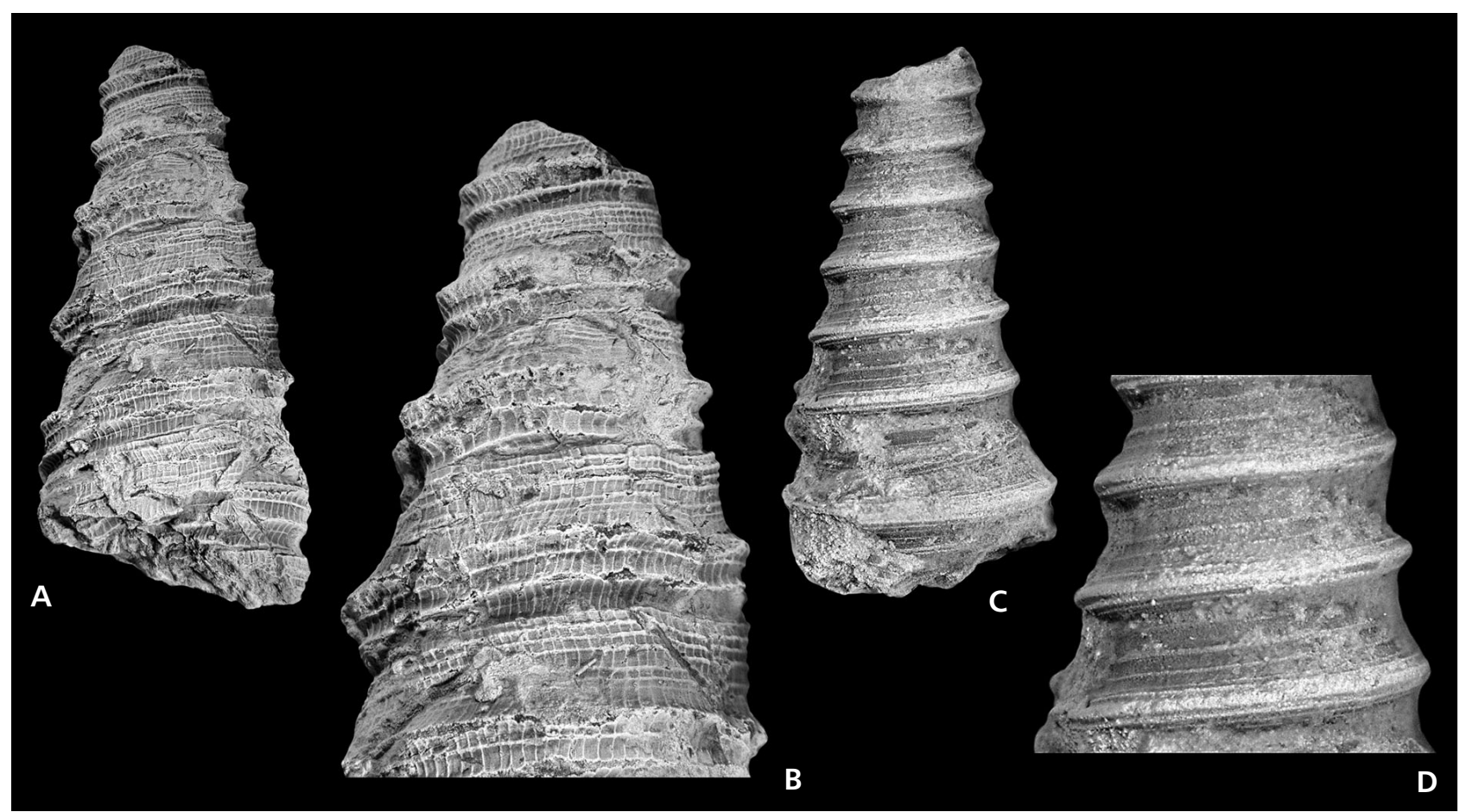

Figure 5. A, B - Carinathilda? textilis (Nützel \& Senowbari-Daryan, 1999), BSPG 2011 XXXIV 19. • A - height $21.5 \mathrm{~mm} \cdot \bullet$ B - detail, height $15 \mathrm{~mm}$. -C, D - Teretrina? sp., BSPG 2011 XXXIV 7. C - height $6 \mathrm{~mm}$; D - detail, height $2.5 \mathrm{~mm}$.

Teretrina? sp.

Figure 5C, D

*1841 Turritella trochleata n. sp. - Münster, p. 118, pl. 13, fig. 12.

1929 Promathildia cf. trochleata. - Douglas, p. 640.

1983 Promathildia (Teretrina) sp. - Fallahi et al., p. 65, pl. 1 , fig. 6 .

1999 Promathildia cf. trochleata. - Nützel \& SenowbariDaryan, p. 124, pl. 6, figs 8-10.

Material. - 1 specimen, BSPG 2011 XXXIV 7.

Description. - Shell is high-spired, slender; illustrated specimen comprises about 7 whorls, $6 \mathrm{~mm}$ high, $3 \mathrm{~mm}$ wide; whorls with prominent spiral keel below mid-whorl; sutures indistinct; whorls covered with fine spiral threads which are especially strong on the keel.

Remarks. - Douglas (1929) described a specimen from the Nayband district as Promathildia cf. trochleata (Münster, 1841); he did not figure it. "Promathildia" trochleata is a high-spired corkscrew-like gastropod from the Cassian Formation resembling the present species from the Nayband Formation. Douglas (1929) mentioned that his specimen is ornamented with spiral striae and thus, it is probably conspecific with the specimens studied here (see also Nützel \& Senowbari-Daryan 1999). Fallahi et al. (1983) fi- gured a relatively large teleoconch fragment of two whorls (15 mm broad) from the Nayband Formation near Isfahan [Promathildia (Teretrina) sp.]. It is very close to our material and is probably conspecific; minor differences in the ornamentation reflect different growth stages.

As mentioned above, the present gastropod species resembles the corkscrew-like "Promathildia" trochleata (Münster, 1841) from the Early Carnian Cassian Formation and was attributed to this species by Douglas (1929) and Nützel \& Senowbari-Daryan (1999). However, examination of the holotype of $P$. trochleata (BSPG AS VII 1822) showed that this species has two strong carinae on the whorls. Large parts of the shell are abraded or covered with matrix. However, some portions show a well-preserved shell surface which has fine strengthened growth lines but lacks any spiral striation. Therefore, "P." trochleata is clearly not conspecific with Teretrina? sp. from the Nayband Formation. Teretrina? sp. resembles Teretrina schulberti Nützel \& Erwin, 2004 from the Norian of Idaho. However, T. schulberti is more slender and has a rather strong spiral rib below the main carination. Teretrina? sp. probably represents a new species. The generic assignment to Teretrina Cossmann, 1912 is tentative because the type species Turritella bolina Münster, 1841 from the Cassian Formation differs is some respects, i.e. it lacks fine spiral lirae and has two distinct spiral ribs (personal observation on the holotype, BSPG AS VII 1821). 
Figure 6. Rarefaction curves of three Late Triassic gastropod collections from the Nayband Formation of Iran; each curve with three most abundant gastropod species (not at scale); Ali Abad is most diverse: 1. Cryptaulax inaequelineata, 2. Rhynchocerithium douglasi, 3. Anulifera binodosa; Dizlu (near Isfahan): 1. Pseudokatosira? seminodosa, 2. Anulifera binodosa, 3. Cryptaulax inaequelineata; Natanz (collection studied herein): 1. Coelostylina conica, 2. Protorcula iranica, 3. Teutonica? natanzensis; all faunas are dominated by high-spired caenogastropods; the fauna from Natanz has the lowest diversity; rank abundance differs strongly in all known gastropod faunas from the Nayband Formation.

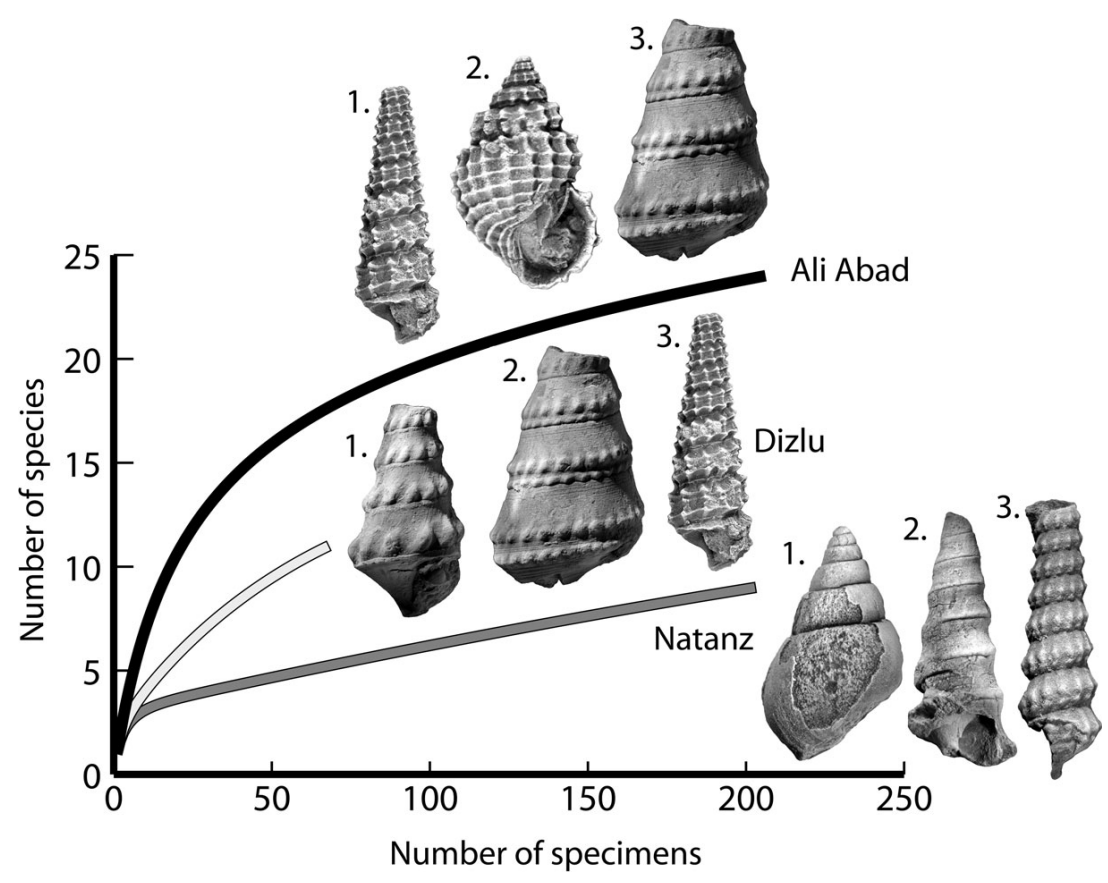

\section{Discussion}

The present gastropod collection from a locality near the town of Natanz, NNE Isfahan comprises 207 specimens and 9 species (Table 1,2). Rarefaction analyses (Fig. 6) and diversity indices (Table 2) indicate that the diversity of the studied fauna is much lower than that from the vicinity of Ali Abad (Tabas region) studied by Nützel \& Senowbari-Daryan (1999) and somewhat less diverse than that of Dizlu (Isfahan region) studied by Nützel et al. (2010). All known gastropod faunas from the Nayband Formation are dominated by more or less high-spired caenogastropods. However, species composition and rank abundance differ strongly in all three gastropod faunas (Fig. 6). The present collection is strongly dominated by Coelostylina conica followed by Protorcula iranica and Teutonica? natanzensis in abundance. In contrast, the three most abundant species at Ali Abad are the cerithioids Cryptaulax inaequelineata and Rhynchocerithium douglasi as well as the protorculid Anulifera binodosa. At Dizlu (near Isfahan), Pseudokatosira? seminodosa, Anulifera binodosa and Cryptaulax inaequelineata are most abundant. It is remarkable that species which dominate the other faunas (Cryptaulax inaequelineata, Anulifera binodosa and Pseudokatosira? seminodosa) are entirely absent in the present collection or very rare (Rhynchocerithium douglasi). These differences in diversity and rank abundance suggest an ecological signal within the Nayband Formation. However, more comprehensive quantitative studies on marine invertebrate faunas of the Nayband Formation are necessary to draw further conclusions. Compared with the highly diverse fauna of the famous Seelan-
Table 1. List of gastropod species and their abundance of the studied gastropod fauna (Nayband Formation near Natanz).

\begin{tabular}{lc}
\hline Species & Individuals \\
\hline Turbinid sp. & 1 \\
Acilia? basistriata & 1 \\
Coelostylina conica & 113 \\
Katosira? lateplicata & 2 \\
Rhynchocerithium douglasi & 1 \\
Teutonica? natanzensis & 32 \\
Protorcula iranica & 54 \\
Teretrina? sp. & 1 \\
Carinathilda? textilis & 2 \\
\hline
\end{tabular}

Table 2. Diversity of three Late Triassic gastropod collections from the Nayband Formation in comparison; the fauna from Natanz is considerably less diverse than that from Ali Abad and somewhat less diverse than that from Dizlu (near Isfahan); all samples were gathered by surface collections.

\begin{tabular}{lccc}
\hline & $\begin{array}{c}\text { Nayband Fm. } \\
\text { Esfahan, Dizlu }\end{array}$ & $\begin{array}{c}\text { Nayband Fm. } \\
\text { Tabas, Ali Abad }\end{array}$ & $\begin{array}{c}\text { Nayband Fm. } \\
\text { Natanz }\end{array}$ \\
\hline Individuals & 68 & 206 & 207 \\
Species & 11 & 24 & 9 \\
Simpson D & 0.67 & 0.94 & 0.61 \\
Shannon H & 1.49 & 2.65 & 1.16 \\
\hline
\end{tabular}

dalpe locality (Cassian Formation, S Tyrol) (e.g., Fürsich $\&$ Wendt 1977), all known gastropod faunas from the Nayband Formation are of low diversity (e.g. Fürsich \& Wendt 1977; Nützel \& Erwin 2004, fig. 15; Nützel et al. 2010). 


\section{Acknowledgements}

The Deutsche Forschungsgemeinschaft is acknowledged for financial support (NU 96/11-1). The Paleontological Society (Journal of Paleontology) and Michael Hautmann (Zürich) are acknowledged for letting us reproduce Figure 1. We thank Joachim Gründel (Berlin) and Andrzej Kaim (Warszawa) for their helpful reviews.

\section{References}

ABBAss, H.L. 1973. Some British Cretaceous gastropods belonging to the families Proceritiidae, Cerithiidae and Cerithiopsidae (Cerithiacea). Bulletin of the British Museum 23, 105-175.

BANDEL, K. 1991. Über triassische "Loxonematoidea" und ihre Beziehungen zu rezenten und paläozoischen Schnecken. $P a$ läontologische Zeitschrift 65, 239-268.

BANDEL, K. 1992. Über Caenogastropoden der Cassianer Schichten (Obertrias) der Dolomiten (Italien) und ihre taxonomische Bewertung. Mitteilungen aus dem Geologisch-Paläontologischen Institut der Universität Hamburg 73, 37-97.

BANDEL, K. 1993. Caenogastropoda during Mesozoic times. Scripta Geologica, special issue 2, 7-56.

BANDEL, K. 1995. Mathildoidea (Heterostropha, Gastropoda) from the Upper Triassic St. Cassian Formation. Scripta Geologica 111, 1-83.

Burmeister, H. 1837. Handbuch der Naturgeschichte, vol. 2. Zoologie, 369-858. Enslin, Berlin.

Conti, M.A. \& Fischer, J.C. 1982. La faune à gastropodes du Jurassique moyen de Case Canepine (Umbria, Italie). Systématique, paleobiogeographie, paléoecologie. Geologica Romana 21, 125-183.

Cossmann, M. 1906-1912. Essais de Paléoconchologie comparée. Livraison: 7 (1906), 261 pp.; 8 (1909), 348 pp.; 9 (1912), 215 pp. The author \& Rudeval, Paris.

Cox, L.R. 1960. Thoughts on the classification of the Gastropoda. Proceedings of the Malacological Society of London 33, 239-261.

Cuvier, G. 1795. Second Mémoire sur l'organisation et les rapports des animaux à sang blanc, dans lequel on traite de la structure des Mollusques et de leur division en ordre, lu à la société d'Histoire Naturelle de Paris, le 11 prairial an troisième [30 May 1795]. Magazin Encyclopédique, ou Journal des Sciences, des Lettres et des Arts, 1795 [1. année] 2, 433-449.

DALL, W.H. 1889. Reports on the results of dredgings ... in the gulf of Mexico and in the Caribbean Sea ... XXIX, Report on the Mollusca, part 2. Gastropoda and Scaphopoda. Bulletin of the Museum of Comparative Zoology 18, 1-492.

Diener, C. 1926. Fossilium Catalogus, I Animalia, 34, Glossophora triadica. 242 pp. W. Junk, Berlin.

Douglas, J.A. 1929. A marine Triassic fauna from Eastern Persia. The Quarterly Journal of the Geological Society of London 85, 624-648. DOI 10.1144/GSL.JGS.1929.085.01-04.20

FALLAHI, M. 1980. Stratigraphie und Fauna der Trias um Isfahan, Persien. 205 pp. Unpublished Ph.D. dissertation, Vienna University.
Fallahi, M., Gruber, B. \& Tichy, G. 1983. Gastropoden und Bivalven aus dem oberen Teil der Nayband-Formation (Obertrias) von Baqirabad (Isfahan, Iran). Schriftenreihe der Erdwissenschaftlichen Kommissionen 5, 57-82.

FrÝdA, J. \& BlodgetT, R.B. 2001. Chulitnacula, a new paleobiogeographically distinctive gastropod genus from Upper Triassic strata in accreted terranes of southern Alaska. Journal of the Czech Geological Society 46(3-4), 299-306.

Fürsich, F.T., Hautmann, M., Senowbari-Daryan, B. \& SeyedEmami, K. 2005. The Upper Triassic Nayband and Darkuh formations of east-central Iran: Stratigraphy, facies patterns and biota of extensional basins on an accreted terrane. Beringeria $35,53-133$.

FÜRSICH, F.T. \& WendT, J. 1977. Biostratinomy and Palaeoecology of the Cassian Formation (Triassic) of the Southern Alps. Palaeogeography, Palaeoclimatology, Palaeoecology 22, 257-323. DOI 10.1016/0031-0182(77)90005-0

GRÜNDEL, J. 1973. Zur Gastropodenfauna aus dem Dogger. I. Die Gattungen Mathilda und Eucycloidea. Zeitschrift für geologische Wissenschaften 1, 947-965.

GRÜNDEL, J. 1997. Heterostropha (Gastropoda) aus dem Dogger Norddeutschlands und Nordpolens. I. Mathildoidea (Mathildidae). Berliner geowissenschaftliche Abhandlungen, Reihe E $25,131-175$.

GRÜNDEL, J. 1999. Die Gattung Teutonica Schröder 1991 (Gastropoda) aus dem Dogger Deutschlands und Nordwestpolens. Paläontologische Zeitschrift 73, 39-45.

GRÜNDEL, J. 2000. Archaeogastropoda aus dem Dogger Norddeutschlands und des nordwestlichen Polens. Berliner Geowissenschaftliche Abhandlungen, Reihe E 34, 205-253.

Hautmann, M. 2001. Die Muschelfauna der Nayband-Formation (Obertrias, Nor-Rhät) des östlichen Zentraliran. Beringeria 29, 3-181.

Hautmann, M., Aghababalou, B. \& Krystyn, L. 2011. An unusual Late Triassic nuculid bivalve with divaricate shell ornamentation and the evolutionary history of divaricate ribs in Triassic bivalves. Journal of Paleontology 85, 22-28. DOI 10.1666/10-013.1

Hébert, M. \& Eudes-Deslongchamps, M.E. 1860. Memoir sur les Fossiles de Montreuil-Bellay (Maine-et-Loire). I. Partie. Céphalopodes et Gastéropodes. Bulletin de la Société Linnéenne de Normandie 5, 153-240.

Kaim, A., Beisel, A.L. \& Kurushin, N.I. 2004. Mesozoic gastropods from Siberia and Timan (Russia) Part 1: Vetigastropoda and Caenogastropoda (exclusive of Neogastropoda). Polish Polar Research 25, 241-266.

KaIM, A. \& ConTI, M.A. 2010. A problematic zygopleuroid gastropod Acanthostrophia revisited. Zitteliana A 50, 21-24.

Kaim, A., Jurkovsek, B. \& Kolar-Jurkovsek, T. 2006. New associations of Carnian gastropods from Mezica region in the Karavanke Mountains of Slovenia. Facies 52, 469-482. DOI 10.1007/s10347-005-0040-2

KIEL, S. 2006. New and little-known gastropods from the Albian of the Mahajanga Basin, Northwestern Madagascar. Journal of Paleontology 80, 455-476. DOI 10.1666/0022-3360(2006)80[455:NALGFT]2.0.CO;2

KitTL, E. 1894. Die Gastropoden der Schichten von St. Cassian der südalpinen Trias. III. Theil. Annalen des KaiserlichKöniglichen Naturhistorischen Hofmuseums 9, 143-277. 
KLIPSTEIN, A. VON 1843. Beiträge zur geologischen Kenntnis der östlichen Alpen. 311 pp. G.F. Heyers Verlag, Gießen.

Kluyver, H.M., Tirrul, L., Chance, P.N., Johns, G.W. \& MeiXNER, H.M. 1983. Explanatory text of the Nayband Quadrangle Map 1: 250,000. Geological Survey of Iran, Geological Quadrangle J8, 1-143.

Knight, J.B., Batten, R.L., Yochelson, E.L. \& Cox, L.R. 1960. Paleozoic and some Mesozoic Caenogastropoda and Opisthobranchia, I310-I324. In Moore, R.C. (ed.) Treatise on Invertebrate Paleontology, Part I, Mollusca 1. Geological Society of America \& University of Kansas Press, Lawrence.

KoKen, E. 1892. Ueber die Gastropoden der rothen Schlernschichten nebst Bemerkungen über Verbreitung und Herkunft einiger triassischer Gattungen. Neues Jahrbuch für Mineralogie, Geologie und Paläontologie 2, 25-36.

KoKen, E. 1896. Die Gastropoden der Trias um Hallstatt. Jahrbuch der kaiserlich-königlichen geologischen Reichsanstalt 46, 37-126.

KoKen, E. 1897. Die Gastropoden der Trias um Hallstatt. Abhandlungen der kaiserlich-königlichen geologischen Reichsanstalt 17, 1-112.

Kutassy, A. 1940. Fossilium Catalogus, I Animalia, 81, Glossophora triadica, 243-477. W. Junk, Berlin.

Laube, G.C. 1868. Die Fauna der Schichten von St. Cassian. III. Abtheilung. Gastropoden. I. Hälfte. Denkschriften der Kaiserlichen Akademie der Wissenschaften. Mathematisch-naturwissenschaftliche Klasse 28, 29-94.

MüNSTER, G. vON 1841. Beschreibung und Abbildung der in den Kalkmergelschichten von St. Cassian gefundenen Versteinerungen, 25-152. In Wissmann, H.L. \& MüNSTER, G. von Beiträge zur Geognosie und Petrefacten-Kunde des Südöstlichen Tirol's vorzüglich der Schichten von St. Cassian 4. Buchner, Bayreuth.

Nützel, A. 1998. Über die Stammesgeschichte der Ptenoglossa (Gastropoda). Berliner Geowissenschaftliche Abhandlungen, Reihe E 26, 1-229.

NüTZEL, A. \& ERwin, D.H. 2004. Late Triassic (Late Norian) gastropods from the Wallowa terrane (Idaho, USA). Paläontologische Zeitschrift 78, 361-416.

NÜTZEL, A. \& GRÜNDEL, J. 2007. Two new gastropod genera from the Early Jurassic (Pliensbachian) of Franconia (South Germany). Zitteliana 47, 61-69.

Nützel, A., Hamedani, A. \& Senowbari-Daryan, B. 2003. Some Late Triassic Gastropods from the Nayband Formation in Central Iran. Facies 48, 127-134. DOI 10.1007/BF02667535

NütZel, A., Mannani, M., Senowbari-Daryan, B. \& Yazdi, M. 2010. Gastropods from the Late Triassic Nayband Formation (Iran), their relationships to other Tethyan faunas and remarks on the Triassic gastropod body size problem. Neues Jahrbuch für Geologie und Paläontologie, Abhandlungen 256(2), 213-228. DOI 10.1127/0077-7749/2010/0049

Nützel, A. \& Senowbari-Daryan, B. 1999. Gastropods from the Upper Triassic (Norian-Rhaetian) Nayband Formation of central Iran. Beringeria 23, 93-132.

RAFINESQue, C.S. 1815. Analyse de la nature, ou tableau de l'univers et des corps organisées. 223 pp. L'auteur \& Jean Barravecchia, Palerme.

Salvini-Plawen, L. von 1980. A reconsideration of systematics in the Mollusca (Phylogeny and higher classification). Malacologia 19, 242-278.

SCHRÖDER, M. 1991. Two Mesozoic ancestors of modern Triphoroidea (Gastropoda), 503-507. In MeIER-BrooK, C. (ed.) Proceedings of the Tenth International Malacological Congress, Tübingen 1989. Unitas Malacologia, Tübingen.

Seyed-Emami, K. 2003. Triassic in Iran. Facies 48, 91-106. DOI 10.1007/BF02667532

SzABÓ, J. 2008. Gastropods of the Early Jurassic Hierlatz Limestone Formation; part 1: a revision of the type collections from Austrian and Hungarian localities. Fragmenta Palaeontologica Hungarica 26, 1-108.

TAte, R. 1869. Contributions to Jurassic Palaeontology. 1. Cryptaulax, a new genus of the Cerithiadae. Annals and Magazine of Natural History 4, 417-419. DOI 10.1080/00222936908696088

TRACEY, S. 2010. 10. Gastropods, 106-155. In Young, J.R., Gale, A.S., Knight, R.I. \& Sмith, A.B. (eds) Fossils of the Gault Clay. Field Guide to Fossil 12. The Palaeontological Association, Wiley-Blackwell.

Wenz, W. 1938-1844. Gastropoda, Teil I. 1639 pp. In Schindewolf, O.H. (ed.) Handbuch der Paläozoologie 6. Bornträger, Berlin.

Wöhrmann, S. von \& KoKEn, E. 1892. Die Fauna der Raibler Schichten vom Schlernplateau. Zeitschrift der Deutschen geologischen Gesellschaft 44, 167-223.

ZAHEDI, M. 1973. Étude géologique de la région de Soh (W de l'Iran Central). Report of the Geological Survey of Iran 27, $1-197$.

ZAPFE, H. 1962. Beiträge zur Paläontologie der nordalpinen Riffe. Ein Massenvorkommen von Gastropoden im Dachsteinkalk des Tennengebirges, Salzburg. Annalen des Naturhistorischen Museums Wien 65, 57-69.

Zardini, R. 1978. Fossili Cassiani (Trias Medio-Superiore). Atlante dei Gasteropodi della formazione di S. Cassiano raccolti nella regione Dolomitica attorno a Cortina D'Ampezzo. 58 pp. Edizione Ghedina, Cortina d'Ampezzo. 